\title{
VEGETATION OF OAT-GRASS MEADOWS IN CENTRAL POLAND
}

\author{
LESZEK KUCHARSKI
}

\begin{abstract}
L. Kucharski, Department of Geobotany and Plant Ecology, Faculty of Biology and Environmental Protection, University of Lodz, Banacha 1/6, 90-237 Łódź, Poland, e-mail: kuchar@biol.uni.lodz.pl
\end{abstract}

(Received: January 9, 2014. Accepted: February 27, 2014)

\begin{abstract}
Communities of hay meadows with Arrhenatherum elatius form phytocenoses of at least two plant communities: Arrhenatheretum elatioris - semi-natural habitats, and Tanaceto-Arrhenatheretum elatioris ruderal habitats. The communities of tall oat-grass include approximately 150 species of vascular plants. In central Poland Tanaceto-Arrhenatheretum is the main habitat for many species characteristic of the Arrhenatherion alliance, including: Pastinaca sativa, Knautia arvensis, Tragopogon pratensis. Hay meadows are vulnerable (VU) components of vegetation of the characterized region. There is a need to verify syntaxonomic units within the Arrhenatherion alliance and phytosociological identifiers of Natura 2000 habitats - extensively used hay lowland meadows (6510).
\end{abstract}

KEY WORDS: Arrhenatherion, meadow, vegetation, Natura 2000, central Poland

\section{INTRODUCTION}

Communities of hay meadows (Arrhenatherion) are considered to be a fairly common component of Polish lowland landscape. The most common one is the community with the dominance of tall oat-grass (Arrhenatheretum elatioris) (MATUSZKIEWICZ 2008). Their prevalence in the country is evidenced by the frequent presence of this community in the lists of protected habitats in Natura 2000 areas. The widely understood Arrhenatheretum elatioris also stands out against other non-forest communities, with rather abundant literature on this topic: geographical distribution, habitat requirements, species abundance and diversity (see Kucharski \& Michalska-Hejduk 1994). The research on plant cover of meadows in central Poland made in the late twentieth century showed that one of the most vulnerable communities in these habitats is Arrhenatheretum elatioris (KUCHARSKI 1999). It is considered to be the endangered component of landscape vegetation in other Polish regions as well (Celiński et al. 1997, Brzeg \& Wojterska 2001, MtynKOWIAK \& KUTYNA 2011).

This paper presents the current state of Arrhenatherum elatius communities in central Poland.

The main objectives of the paper are:

- determination of the diversity of communities of Arrhenatherum elatius occurring in central Poland,
- comparison of oat-grass communities in rural areas with the tall oat-grass communities in urban areas,

- presenting the degree of threat of tall oat-grass communities in central Poland.

\section{CHARACTERISTICS OF THE STUDY AREA}

Central Poland is considered to be the central part of the country, which includes the area of the Lodz region and the neighboring municipality regions, adjacent to the boundaries. This area coincides with the Central Poland area, as described by MowszowICZ (1978). This geomorfologically diverse area lies on the border between the provinces of Central European Lowland and Polish Highlands. It consists of Silesian-Cracow Highland and Małopolska Highland, where Mesozoic and Paleozoic rocks come onto the surface, and even of Central Poland Plain and South Baltic Lake District, composed of Quaternary sediments (KONDRACKI 2002). In the geobotanical division of the country by SzAFER (1977), this area has a transitional, lowland-highland nature. The southern part lies in the northern part of the Central Highlands Belt and the northern part in the Belt of the Great Valleys. 
The area is characterised by a lowering of the surface to more than $300 \mathrm{~m}$ above sea level in the south to $80 \mathrm{~m}$ above sea level in the north (TurKowsKa 2001). The feature of this area is also a shortage of water, which is a consequence of, among others: the position in the watershed of the Vistula and Oder rivers and significant deforestation area (lowest forest cover in Poland) (MAKsymiuk 2001). The climate of the area is characterized by a relatively small spatial diversity. The largest differences were noted in precipitation, ranging from $500 \mathrm{~mm}$ in the north of the region, to more than $600 \mathrm{~mm}$ in the upland part (KŁYSIK 2001).

\section{MATERIALS AND METHODS}

The study covers the results of field studies carried out in the grassy central Poland plant communities in 2000-2013. It presents preliminary data on diversity of communities of Arrhenatherum elatius and their distribution, trends in vegetation and the degree of threat. The object of the study was plant cover of hay meadows used in agriculture, lawns in urban areas (mown no more often than twice a year) and roadsides (mown at least once a year). In uniform vegetation patches over 50 phytosociological relevés were taken by Braun-Blanquet method, 48 of which are presented in Table 1 (PAwıowski 1977). Phytosociological relevés on roadsides were taken in strips of vegetation not narrower than $4 \mathrm{~m}$.

For distinguished plant communities, values of forming them plant systematic species communities were calculated (PAwŁOWSKI 1977). Syntaxonomy of

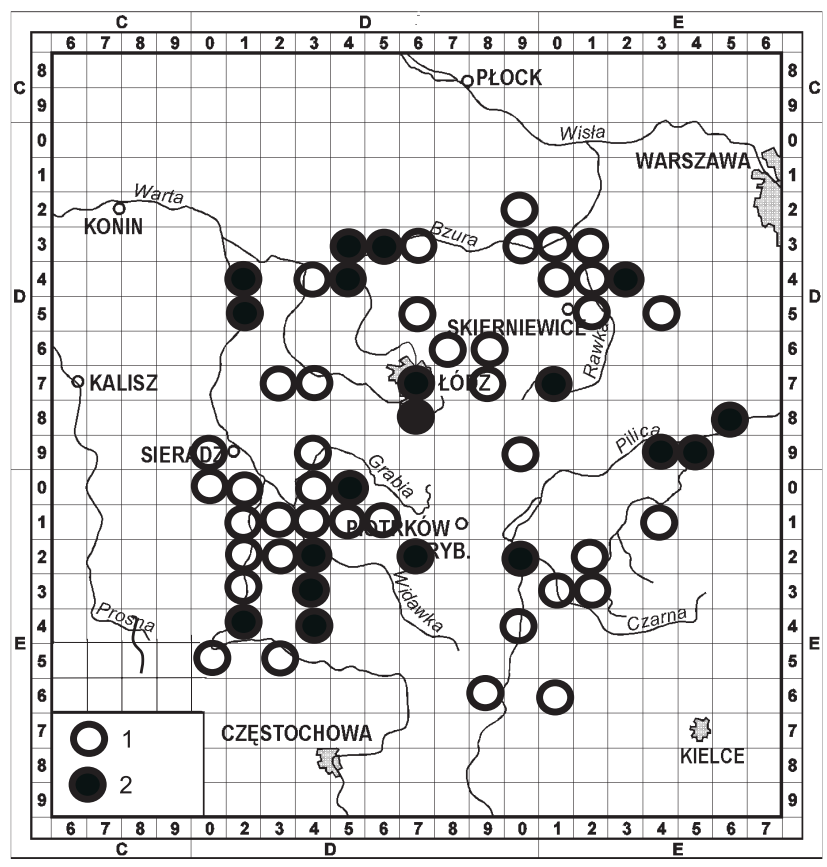

Fig. 1. Distribution of Arrhenatheretum elatioris and Tanaceto-Arrhenatheretum elatioris in central Poland: 1 - locality reported till 1999, 2 - locality identified or confirmed in 2000-2013 recorded species is presented according to MatuszKIEWICZ (2008). Nomenclature of vascular plants is consistent with Mirek et al. (2002). Distribution of Arrhenatherum elatius meadows in central Poland is shown in cartogram (Fig. 1). A large-scale ATPOL cartogram of the side of a square $10 \mathrm{~km}$ was used (ZAJĄC 1978). Due to the small share of bryophytes in plant cover patches these plants were omitted in further analyses.

\section{RESULTS}

Current results of studies of the plant cover of meadows in central Poland indicate that grass monocultures are the dominant component of the plant cover on economically used grasslands. Hay grassland habitats are affected to a greater extent than wet ones. This process is accompanied by withdrawal of some of the species associated with the extensively used hay meadows from these habitats. They participate in the formation of new plant communities built by species characteristic of the Arrhenatherion alliance in ruderal habitats (including urban lawns and roadsides).

Arrhenatherum elatius is one of the most important grasses occurring on grasslands. It is a species characteristic for the Arrhenatheretum elatioris which is the most typical form of Arrhenatherion alliances. This species is also listed in grassland communities developing in ruderal areas. Phytocenoses of communities with tall oat-grass studied in 2000-2013 were built by about 150 species of vascular plants, representing over $30 \%$ of taxa recorded in the meadows of central Poland (KUCHARsKi 1999). In phytocenoses of Arrhenatherum elatioris occurring on agricultural land, 137 species of vascular plants were found. Patches of Tanaceto vulgaris-Arrhenatheretum elatioris were created by 77 species of vascular plants.

Initial results have shown that in central Poland, tall oat-grass and species characteristic for Arrhenatherion elatioris alliance create at least two plant communities: Arrhenatheretum elatioris and Tanaceto vulgaris-Arrhenatheretum elatioris.

Here is their syntaxonomy and diversity:

Class: Molinio-Arrhenatheretea R.Tx. 1937

Order: Arrhenatheretalia Pawł. 1928

Alliance: Arrhenatherion (Br.-Bl. 1919) Koch 1926

Arrhenatheretum elatioris (Br.-Bl. 1919) Koch 1926

- typicum

- brizetosum mediae

- alchemilletosum

- dactyletosum

- heracleoetosum

- sanguisorbetosum officinalis

- alopecuro-polygonetosum bistortae.

Tanaceto vulgaris-Arrhenatheretum elatioris Fischer ex Ellmauer in Mucina et al. 1993. 


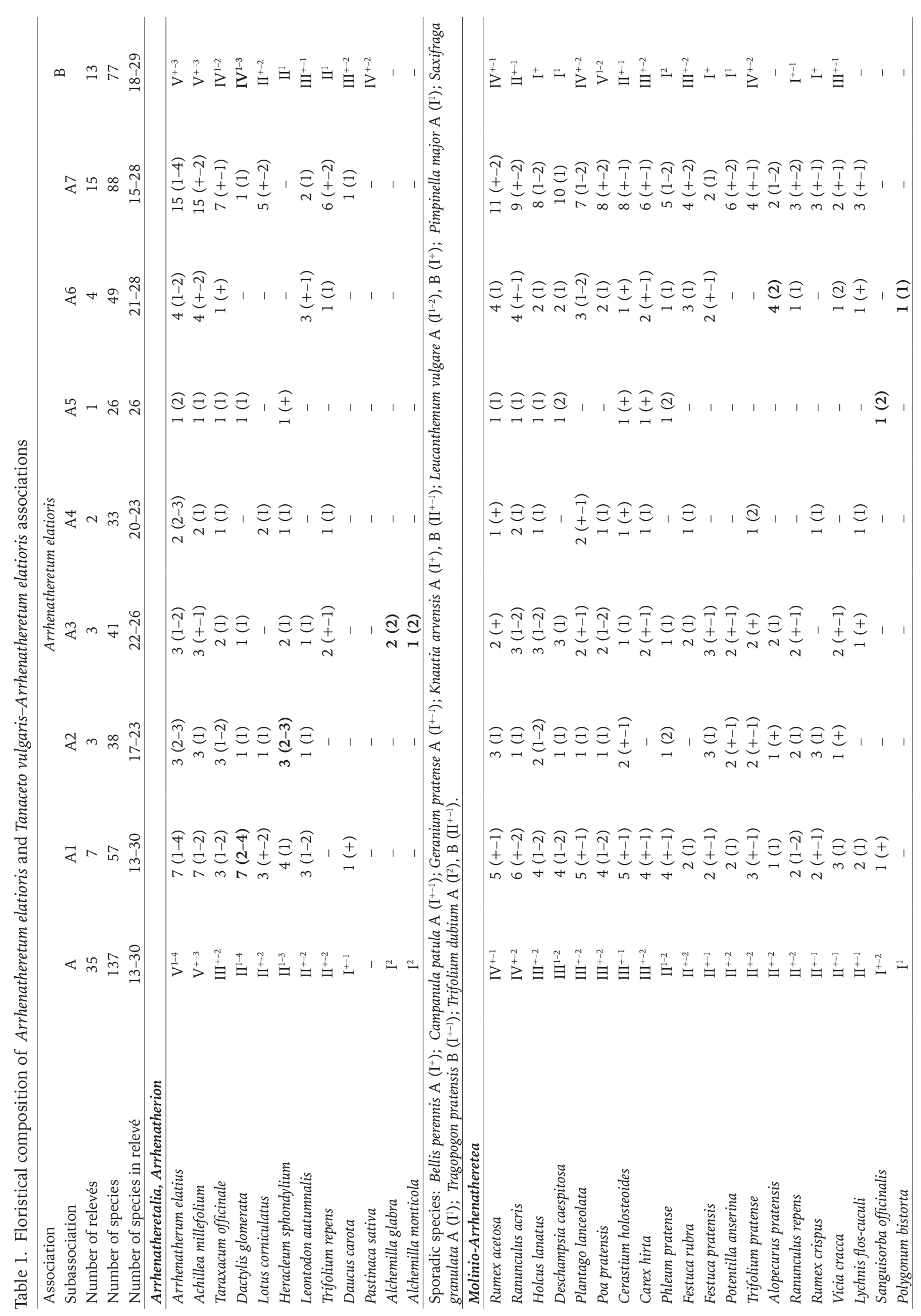




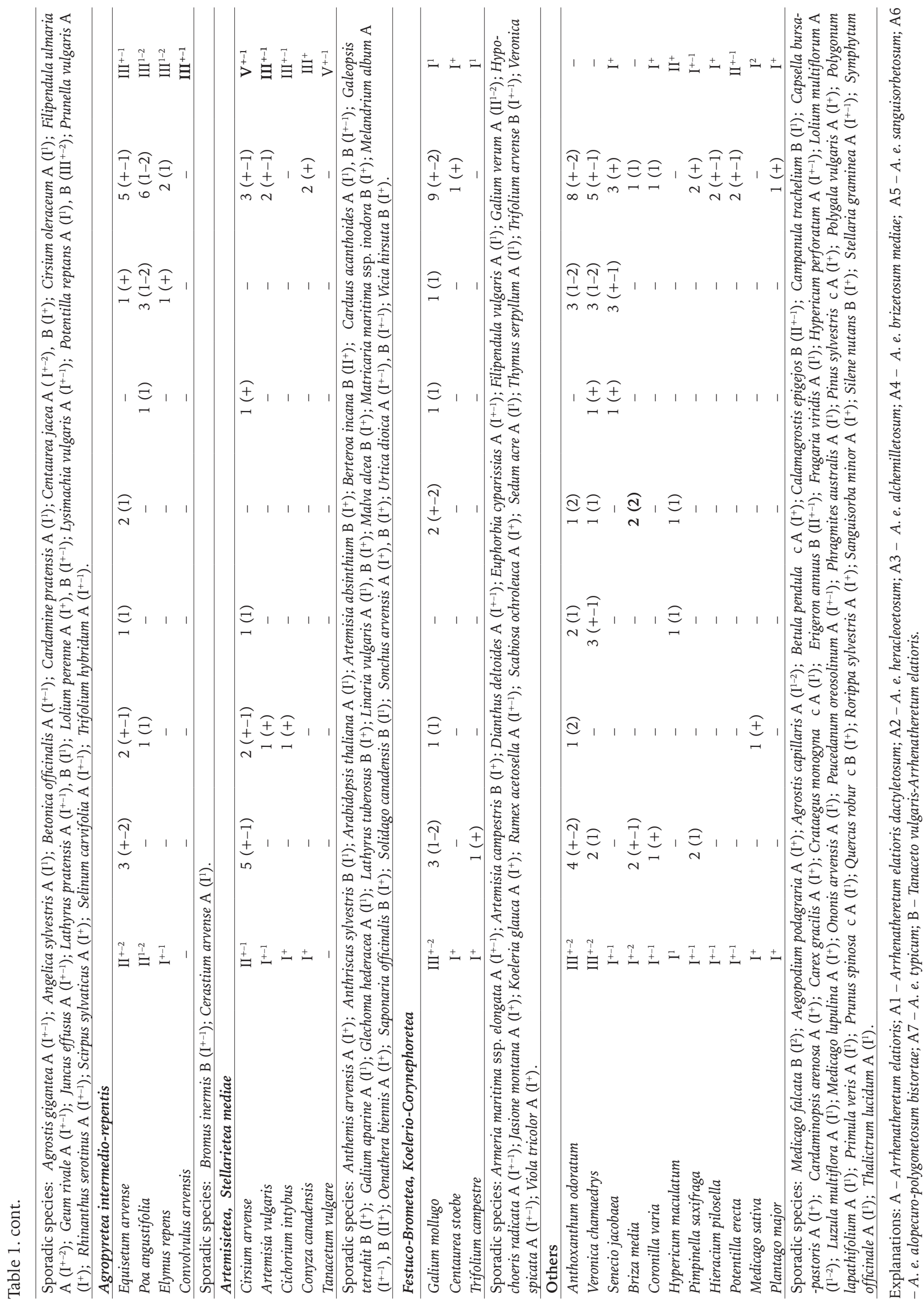


Arrhenatheretum elatioris was reported on extensively used meadows, both on the terraces of river valleys lagoon territories and beyond. Seven syntaxonomic units of the rank of sub-association were found (Table 1). The most frequently reported was Arrhenatheretum elatioris typicum. It is characterised by a very diverse floristic composition; in addition to tall oat-grass and yarrow, species characteristic for Molinio-Arrhenatheretea appear with great frequency. It is usually recorded in river valleys, rarely beyond. One of the more interesting syntaxa is Arrhenatheretum elatioris alchemilletosum, which usually is described in the southern regions of the country (see KUCHARSKI \& MichalsKa-Hejduk 1994). In the describrd area it was found in the south, usually outside the river valleys or on small upland fields in the valleys of large rivers. The community is extensively grazed. Arrhenatheretum elatioris brizetosum mediae is the most "natural" community of the above syntaxa. It was noticed on the most neglected meadows, rarely mown and fertilized, and growing on acidic and not very fertile soil. On more fertile and moist habitats of variable humidity, phytocenoses of $A$. e. sanguisorbetosum officinalis are recorded. Phytocenoses with a large share of common hogweed (A. e. heracleoetosum) develop on mineral-organic surface. These are meadows fertilized and mown twice a year. In the valleys of large rivers (the Warta, Pilica, Bzura) of a relatively fertile ground, patches A. e. alopecuro-polygonetosum bistortae communities are reported. The most common syntaxonomic unit on hay meadows is A. e. dactyletosum. Phytocenoses develop on damp habitats within intensively used meadow complexes.

Phytocenoses of Arrhenatherum elatius with significant participation of species of Artemisietea vulgaris and Agropyretea intermedio-repentis were described, among others, on the area of Giessen (Hesse) as ruderal meadows ("Ruderale Wiesen") - Tanaceto vulgaris-Arrhenatheretum elatioris (FISCHER et al. 1985). Similar community on the area of Berlin has been described as Dauco-Arrhenatheretum elatioris (KowARIK \& LANGER 1994) and on roadsides in the western part of Germany (Ullmann et al. 1990). Tanaceto-Arrhenatheretum also reported on the area of Austria (MüLLER 1995, Essl 2005) and Bulgaria (Velev et al. 2011). Diagnostic species of the communities are: Artemisia vulgaris, Cirsium arvense, Convolvulus arvensis and Dactylis glomerata. Permanent components of this syntaxon include: Achillea millefolium, Arrhenatherum elatius, Elymus repens and Taraxacum officinale (Velev et al. 2011). In the region of Lodz, ruderal habitats (lawns, roadsides) are home to relatively floristically rich communities in which tall oat-grass is accompanied by: Pastinaca sativa, Daucus carota, Cirsium arvense, Heracleum sphondylium, Knautia arvensis and species of Artemisietea class, as well as and thermophilic grasslands. They were described as Tanaceto vulgaris-Arrhenatheretum. So far, that community has not been described on the Polish
Table 2. Systematic value of species groups in Arrhenatheretum elatioris and Tanaceto vulgaris-Arrhenatheretum elatioris

\begin{tabular}{lrr}
\hline \multicolumn{1}{c}{ Species group } & \multicolumn{1}{c}{ c } & \multicolumn{1}{c}{2} \\
\hline Arrhenatherion & 27.52 & 30.00 \\
Arrhenatheretalia & 10.42 & 24.21 \\
Molinietalia & 4.75 & - \\
Molinio-Arrhenatheretea & 65.10 & 36.63 \\
Festuco-Brometea & 1.61 & 1.26 \\
Koelerio-Corynephoretea & & \\
Artemisietea vulgaris & 1.43 & 19.89 \\
Agropyretea intermedio-repentis & 4.06 & 15.47 \\
\hline Others & 7.64 & 9.11 \\
\hline
\end{tabular}

Explanations: 1 - Arrhenatheretum elatioris, 2 - Tanaceto vulgaris-Arrhenatheretum elatioris.

territory. Patches of the community have a significant share of species characteristic for hay meadows and ruderal habitats (Artemisietea and Agropyretea intermedio-repentis) and a small proportion of species characteristic for other types of meadows (Molinio-Arrhenatheretea; Table 2). They are also characterised by higher species richness. On the phytosociological relevés taken on the Tanaceto-Arrhenatheretum patch, 23 species of vascular plants were reported on average, while in case of Arrhenatheretum elatioris their number is slightly above 20 species.

\section{DISCUSSION}

Arrhenatherum elatius is short-term grass of high development dynamics but largely dependent on management. This grass does not tolerate very low mowing, grazing and trampling. Cessation of use (mowing) causes replacement of it by nitrophilous perennials. After cessation of fertilization on very fertile habitats, it is displaced by species of psammophilous grasslands (SzERAFIMOWICZ 1960, JANKOWSKa 1967, Henn et al. 1988, Kornaś \& Dubiel 1990, FALKOWSKI et al. 1994).

In most works devoted to meadows published in the twentieth century, communities with tall oat-grass were treated as collective communities of Arrhenateretum elatioris (previously Arrhenatheretum medioeuropaeum). Numerical methods for the analysis of phytosociological records caused the division of the syntaxon into a couple of smaller plant communities. These include: Pastinaco sativae-Arrhenatheretum elatioris Passarge 1964 (considered as a synonym for Arrhenatheretum elatioris), Ranunculo bulbosi-Arrhenatheretum elatioris Ellmauer in Mucina et al. 1993, Ranunculo repentis-Alopecuretum pratensis (Eggler 1933) Ellmauer in Mucina et al. 1993, Tanaceto vulgaris-Arrhenatheretum elatioris Fischer ex Ellmauer in Mucina et al. 1993, Lilio bulbiferi-Arrhenatheretum elatioris Ružičková 2002 (ŠKODOVÁ \& JANIŠOVÁ 2008, JANIŠOVÁ et al. 2010, Opera \& Sîrbu 2010, Velev et al. 2011, Lengyel et al. 2012). In Poland, the community is still described as Arrhenatheretum elatioris (KRYSZAK 2001, 
Bator 2005, Kozłowska 2005, Kryszak et al. 2008). The above-mentioned facts point to the need of verification of the currently used classification of hay meadows plant cover (Arrhenatherion) in Poland.

Oat-grass meadows (habitat 6510) have been considered a fairly common component of the landscape in central Poland. It is proven by the fact that they are frequently mentioned in Standard Data Forms as non-forest plant cover habitat in Natura 2000 areas. In the 90s of the 20th century, they covered the area of 11,230 ha (Table 3). The verification of data for Protection Tasks Plans for chosen objects indicates that the surface has been significantly reduced since the $90 \mathrm{~s}$ of the 20th century. In the Pradolina Bzury-Neru, the 6510 habitat currently occupies less than $10 \%$ of the area recorded in the nineties of the previous century. Studies in other areas of the Natura 2000 sites in central Poland confirmed the above-mentioned phenomenon (KuCHARSKi 2013). Currently extensively used Arrhenatherion elatioris hay meadows are considered vulnerable (V) in the Lodz region (KUCHARSKI 2012, KuCHARSKI et al. 2012). The situation has been affected by the changes in grassland management, including, among others: intensification or abandonment of use, change of grassland to cropland, and the mechanization of hay harvesting. They caused that the surface of the primary alliance Arrhenatherion - Arrhenatheretum elatioris - has dramatically decreased. Existing phytocenoses of this community are characterized by low species richness. In semi-natural hay meadows in central Poland the species considered to be characteristic of these habitats have been withdrawing. They include as follows: Pastinaca sativa, Knautia arvensis, Tragopogon pratensis, and Geranium pratense. It is noted that some of them enter substitute habitats, which include ruderal meadows (Table 1).

Table 3. Participation of extensively used lowland hay meadows (6510) in the area of Natura 2000 sites in central Poland (based on Standard Data Form)

\begin{tabular}{rlrrr}
\hline No. & \multicolumn{1}{c}{ Name of SAC } & $\begin{array}{c}\text { Area } \\
\text { of SAC } \\
\text { (ha) }\end{array}$ & $\begin{array}{c}\% \\
\text { of cover } \\
\text { habitat }\end{array}$ & $\begin{array}{c}\text { Surface } \\
\text { of habitat } \\
\text { (ha) }\end{array}$ \\
\hline 1 & Pradolina Bzury-Neru & 21,886 & 17.00 & 3,721 \\
2 & Załęczański Łuk Warty & 9,317 & 1.50 & 140 \\
3 & Dolina Środkowej Pilicy & 3,787 & 14.00 & 530 \\
4 & Dolina Rawki & 2,525 & 70.00 & 1,768 \\
5 & Grabia & 1,671 & 87.50 & 1,462 \\
6 & Lipickie Mokradła & 370 & 10.00 & 37 \\
7 & Polany Puszczy Bolimowskiej & 132 & 55.00 & 73 \\
8 & Łąki Ciebłowickie & 475 & 7.00 & 33 \\
9 & Dolina Dolnej Pilicy & 31,822 & 0.50 & 159 \\
10 & Ostoja Przedborska & 11,605 & 6.00 & 696 \\
11 & Dolina Czarnej & 5,781 & 0.50 & 29 \\
12 & Dolina Górnej Pilicy & 11,193 & 17.70 & 1,981 \\
13 & Dolina Środkowej Warty & 60,140 & 1.00 & 601 \\
\hline
\end{tabular}

\section{SUMMARY AND CONCLUSIONS}

Oat-grass meadows in central Poland are the habitat for about 150 species of vascular plants, representing over $30 \%$ of taxa recorded in central Poland meadows.

In central Poland there are at least two communities, in which Arrhenatherum elatius makes a significant part in the patches. They are: Arrhenatheretum elatioris and Tanaceto vulgaris-Arrhenatheretum elatioris.

There is an urgent need to revise the currently used classification of communities in Poland within the Arrhenatherion elatioris alliance and adapting it to the system used in Central Europe.

Action should be taken to protect extensively used hay meadows, especially in the habitat areas of Natura 2000.

It is advisable to develop new phytosociological identifiers in order to assess 6510 habitat - extensively used lowland hay meadows (Arrhenatherion).

\section{REFERENCES}

BATOR I. (2005): Stan obecny i przemiany zbiorowisk łąkowych okolic Mogilan (Pogórze Wielickie) w okresie 40 lat. Fragmenta Floristica et Geobotanica Polonica Supplement 7: 1-97.

Brzeg A., Wojterska M. (2001): Zespoły roślinne Wielkopolski, ich stan poznania i zagrożenia. In: M. Wojterska (ed.). Szata roślinna Wielkopolski i Pojezierza Południowopomorskiego. Przewodnik sesji terenowych 52. Zjazdu PTB. Bogucki Wydawnictwo Naukowe, Poznań: 39-110.

Celiński F., Wika S., Parusel J. B. (eds) (1997): Czerwona lista zbiorowisk roślinnych Górnego Śląska. Centrum Dziedzictwa Przyrody Górnego Śląska. Raporty Opinie 2: 38-68.

EssL F. (2005): Invasionsgeschichte und pflanzensoziologischer Anschluss der Alppohire (Sorghum halepense) am Beispiel des östlichen Oberösterreich. Floristisch-sozologische Arbeitsgemeinschaft e. V. 25: 251-268.

Falkowski M., KukuŁKa I., KozŁowski S. (1994): Właściwości biologiczne roślin łąkowych. Wybrane zagadnienia. Wydawnictwo Akademii Rolniczej w Poznaniu, Poznań.

Fischer A., Rugel O., Rattay R. (1985): 'Ruderale Wiesen' - Ein Beitrag zur Kenntnis des Arrhenatherion-Verbandes. Tuexenia 5: 237-248.

Henn H., Petit D., Vernet P. (1988): Interference between Hieracium pilosella and Arrhenatherum elatius in collery spoils of north of France. Allelopathy or competition? Oecologia 78: 268-272.

Janišová M., Uhliarová E., RuŽičKová H. (2010): Expert system-based classification of semi-natural grasslands in submontane and montane regions of central Slovakia. Tuexenia 30: 375-422. 
JANKOWSKA K. (1967): Sezonowe zmiany roślinności i produkcja pierwotna netto w płacie łąki Arrhenatheretum elatioris. Studia Naturae Ser. A 1: 153-175.

KŁYsıK K. (2001): Warunki klimatyczne. In: S. Liszewski (ed.). Zarys monografii województwa łódzkiego. Łódzkie Towarzystwo Naukowe, Łódź: 68-81.

KONDRACKI J. (2002): Geografia regionalna Polski. Wyd. Nauk. PWN, Warszawa.

KornAś J., Dubiel E. (1990): Przemiany zbiorowisk łąkowych w Ojcowskim Parku Narodowym w ostatnim trzydziestoleciu. Prądnik, Prace Muzeum Szafera 2: 97-106.

KowARIK I., LANGER A. (1994): Vegetation einer Berliner Eisenbahnfläche (Schöneberger Südgelände) im vierten Jahrzehnt der Sukzession. Verhandlungen des Botanischen Vereins von Berlin und Brandenburg 127: 5-43.

KozŁowsKa T. (2005): Zmiany zbiorowisk łąkowych na tle różnicowania się warunków siedliskowych w charakterystycznych obszarach dolin rzecznych Polski centralnej. Woda-Środowisko-Obszary Wiejskie. Rozprawy naukowe i monografie 14 .

KRYSZAK A. (2001): Różnorodność florystyczna zespołów łąk i pastwisk klasy Molinio-Arrhenatheretea R. Tx. 1937 w Wielkopolsce w aspekcie ich wartości gospodarczej. Roczniki Akademii Rolniczej w Poznaniu. Rozprawy Naukowe 314.

Kryszak A., Kryszak J., KlarzyŃsKa A. (2008): Wpływ warunków siedliskowych i użytkowania na kształtowanie się Arrhenatheretum elatioris. Woda-Środowisko-Obszary Wiejskie 8(1): 175-184.

KuCHARSKI L. (1999): Szata roślinna łąk Polski środkowej i jej zmiany w XX stuleciu. Wydawnictwo Uniwersytetu Łódzkiego, Łódź.

KuCHARSKI L. (2012): Roślinność łąkowa środkowej Polski na przełomie XX i XXI wieku - jej stan, kierunki zmian i ochrona. Ekologia i Technika 20(1): 19-25.

KUCHARSKI L. (2013): Zbiorowiska łąkowe z klasy Molinio-Arrhenatheretea w ostojach Natura 2000 na obszarze środkowej Polski. Typescript. Zakład Ochrony Przyrody, Uniwersytet Łódzki, Łódź.

Kucharski L., Michalska-Hejduk D. (1994): Przegląd zespołów łąkowych z klasy Molinio-Arrhenatheretea stwierdzonych w Polsce. Wiadomości Botaniczne 38(1-2): 95-104.

Kucharski L., Michalska-Hejduk D., Kopeć D., OlaCZEK R. (2012): Zbiorowiska solniskowe, łąkowe i torfowiskowe. In: R. Olaczek (ed.) Czerwona księga roślin województwa łódzkiego. Zagrożone rośliny naczyniowe. Zagrożone zbiorowiska roślinne. Ogród Botaniczny w Łodzi, Uniwersytet Łódzki, Łódź: 246-261.

Lengyel A., Purger D., Csiky J. (2012): Classification of mesic grasslands and their transitions of South Transdanubia (Hungary). Acta Botanica Croatica $71(1): 31-50$.
Maksymiuk Z. (2001): Wody. In: S. Liszewski (ed.). Zarys monografii województwa łódzkiego. Łódzkie Towarzystwo Naukowe, Łódź: 60-68.

Matuszkiewicz W. (2008): Przewodnik do oznaczania zbiorowisk roślinnych Polski. Wyd. Nauk. PWN, Warszawa.

Mirek Z., PięKoś-Mirkowa H., ZająC A., ZająC M. (2002): Flowering plants and pteridophytes of Poland. A checklist. Vol. 1. Biodiversity of Poland. - Krytyczna lista roślin naczyniowych Polski. T. 1. Różnorodność biologiczna Polski. W. Szafer Institute of Botany, Polish Academy of Sciences, Kraków.

MŁYnKowiak E., Kutyna I. (2011): Zróżnicowanie zbiorowisk łąkowych klasy Molinio-Arrhenatheretea w krajobrazie zachodniej części Pojezierza Drawskiego. Łąkarstwo w Polsce 14: 85-103.

Mowszowicz J. (1978): Conspectus Florae Poloniae Medianae (Plantae vasculares). - Przegląd flory Polski Środkowej (rośliny naczyniowe). Uniwersytet Łódzki, Łódź.

MüLleR N. (1995): River dynamics and floodplain vegetation and their alterations due to human impact. Archiv für Hydrobiologie Suppl. 101(3/4): 477-512.

Opera A., Sîrbu C. (2010): Phytocoenotic surveys on some mesotrophic - eutrophic marshes in eastern Romania. Journal of Plant Development 17: 75-108.

PAwŁowski B. (1977): Skład i budowa zbiorowisk roślinnych oraz metody ich badania. In: W. Szafer, K. Zarzycki (eds). Szata roślinna Polski. Vol. 1. Państwowe Wydawnictwo Naukowe, Warszawa: 237-269.

ŠKodovÁ I., JANišOvÁ M. (2008): The classification of Slovak grassland communities to the higher syntaxonomical units. Annali di Botanica Roma 8: $31-42$.

Szafer W. (1977): Szata roślinna Polski. Vol. 2. Eds W. Szafer, K. Zarzycki. Państwowe Wydawnictwo Naukowe, Warszawa: 17-188.

SzERAFIMOWICZ N.G. (1960): Izucheniye biologicheskoj raznorodnosti populacji rajgrasa vysokogo Arrhenatherum elatius. Geobotanica 12: 196-210.

TuRkowsKa K. (2001): Budowa geologiczna i rzeźba terenu. In: S. Liszewski (ed.). Zarys monografii województwa łódzkiego. Łódzkie Towarzystwo Naukowe, Łódź: 51-60.

Ullmann I., Heindl B., Schug B. (1990): Naturräumliche Gliederung der Vegetation auf Straßenbegleitflächen im westlichen Unterfranken. Tuexenia 5: 197-222.

Velev N., Apostolova I., Rozbrojová Z. (2011): Alliance Arrhenatherion in West Bulgaria. Phytologia Balcanica 17(1): 67-78.

ZajĄC A. (1978): Założenia metodyczne „Atlasu rozmieszczenia roślin naczyniowych w Polsce”. Wiadomości Botaniczne 22(3): 145-155. 